る塑性せん断変形，構造物の塑性理論の進歩.

$$
\text { [神馬敬] }
$$

\section{$389.6(410): 621.791$}

[524]溶接に関するイギリス規格の展望［R.J. Lewis, Weld. Metal Fabr., 1968-4, Vol. 36, No. 4, p. $149 \sim 155$, 表 2] イギリスの溶接規格の分類は 溶接施工法では抵抗溶接, アーク溶接, ガス溶接, 万 う付に大別されこれに試験および検查法が付随してい る。また溶接関連規格として溶接用語および溶接記 号, ガス切断, 安全規格, 溶接装置などがある. 溶接 規格番号を示すと，次のとおりである.

(a) 抵抗溶接 $3065 ， 4129 \rightarrow$ フラッシュ溶接 4204, 点溶接 $807,1140,4215$, シーム溶接 2937,3067 , マ ッシュシーム溶接 3847 , プロゼクション溶接 2630 , 2996, 3856.

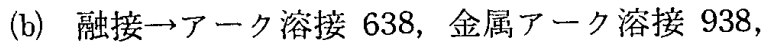
$1856,2633,2642,2971$, 手動アーク溶接 639,1719 part 1，2493，2926. サブマージアーク溶接 4165, ミ グ溶接 2901 part 2, 3571. ティグ溶接 2901 part 1, 3019 part 1，2. ガス溶接 $1126,1389,1453$, 酸素アセ チレン溶接 $693,1821,2640$.

(c) 万う接 $1724,1723,1845$.

(d) 試験および検查関係 (1) 溶接工 1295，2645 part 1,2. (a) 点溶接 1138 , (4) 融接 $709,1077,3451$, 4206 ， $\Leftrightarrow$ 放射線検查 $2600 ， 2910$, (林) 超音波検査 2923 part 1, 2, 3 .

(e) 溶接用語, 溶接記号 499 part 1，2，499c.

(f) 安全関倸 $2653,1542,678$. [妹島 五彦]

621.791.75.052 : 624.078.3

[525]造船およびタンク組立に応用せる片面自動溶 接 [D. Ing. J. Keuderesi, Brit. Weld. J., 1967-9, Vol. 14, No. 9, p. 467 476, 図 13, 表 4]サブ マージアーク溶接方式による片面自動溶接法は 1953 年ごろより日本，イギリスおよびソ連の造船所におい て適用されているが，その適用は造船，タンク類の組 立に抄いて主として板厚 6 22 $\mathrm{mm}$ の平板の乫合せ溶 接に用いられている.この方法のかなめとなるものは

\begin{tabular}{|c|c|c|c|c|}
\hline$t:$ 板 厚 $\mathrm{mm}$ & 6 & 8 & 10 & 12 \\
\hline$g:$ 間げさ $\mathrm{mm}$ & 1.5 & 2 & 2.5 & 3 \\
\hline 溶接電流 $\mathrm{A}$ & 650 & 800 & 880 & 1000 \\
\hline アーク電任 $V$ & $28 \sim 33$ & $39 \sim 32$ & $30 \sim 32$ & $32 \sim 33$ \\
\hline 溶接速度 $\mathrm{cm} / \mathrm{min}$ & 75 & 65 & 55 & 50 \\
\hline
\end{tabular}

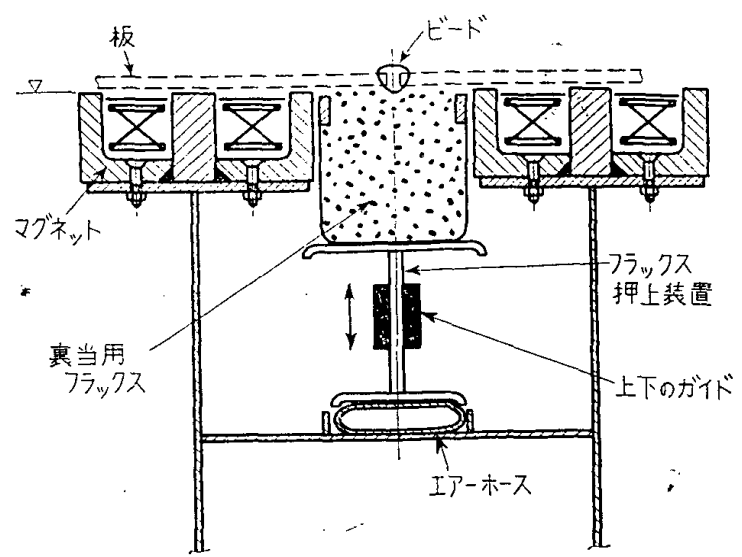

図 53 マグネット方式の裹押え装置

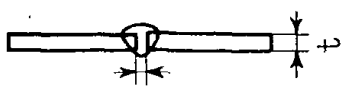

$(g)$

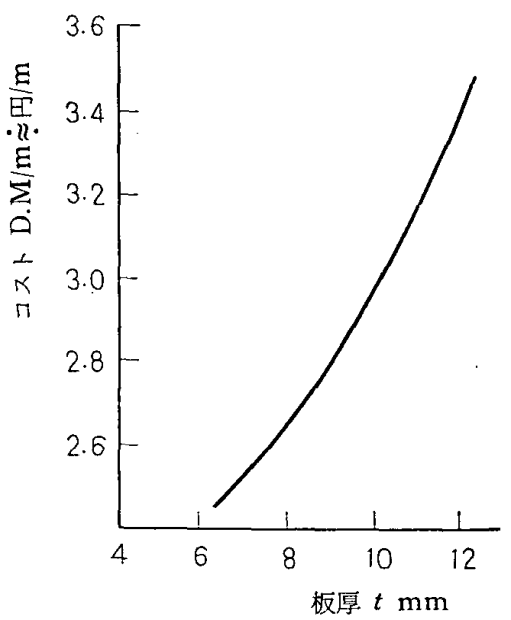

図 54 摩面自動溶接のコスト

平板の押え装置であり，図 53 に示すようにマグネッ トテーブルが採用されている，溶接条件の一例を示す とつぎのと扔りでこの場合の溶接線 $1 \mathrm{~m}$ 当たりの価 額を示すと図 54 の上らである.

[姝島五彦]

\subsubsection{5:658.5}

[526]農業機械の組立における溶接機械化の拡大

[J.H. Weaver, Weld. J., 1968-4, Vol. 47, No. 4, p. 317 321, 図 8] 著書はリンカン電気会社の技 師で農業機械を製作するへストン製作所が 1947 年 5 人で企業を始め今日では従業員 1045 人, イタリアに も子会社を持ち年間売上げ 2000 万ドルに成長した想 定において溶接の機械化をどのように達成したかにつ いて数例をあげて説明している.この会社の溶接の機 械化は $60 \%$ におよび, 自動, 半自動溶接を大幅に採 用している. 手溶接にも鉄粉入りの E 7024 系統の溶 接棒を使って能率をあげている．自動溶接には単極サ ブマージアーク， 2 電極法，オープンアーク溶接法が 主力をなしている．応用例として乾草機の溶接につい て述べると従来 1 日 23〜25 台の生産が現今は 35〜40 台に能率向上されている.

[妹尾五浐]

\subsection{3:624.046: 539.4.013.1}

[527]機械構造物溶接部への忍力負荷状況 [J.L. Lass, Weld. Design \& Fabr., 1968-3, Vol. 41, No. 3, p. 84 85, 図 4, 表 2] 溶接構造物は現在ではご く一般的に用いられている。しかし，支る設計者によ ると安全率を非常に大きくとりすぎている場合もあ

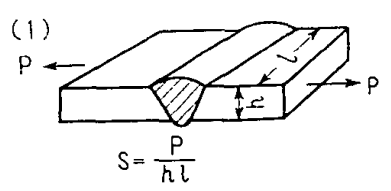

(2)
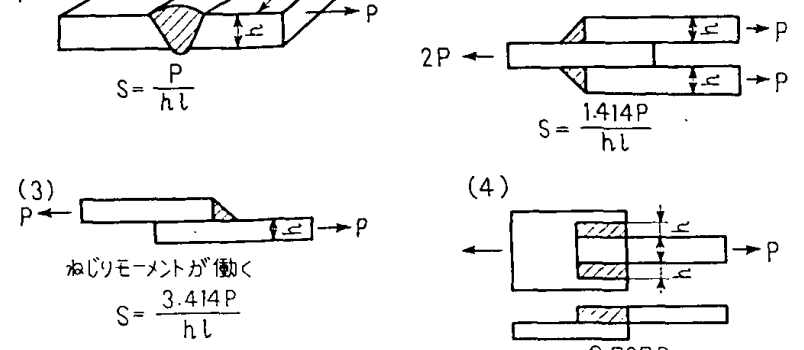

(4)

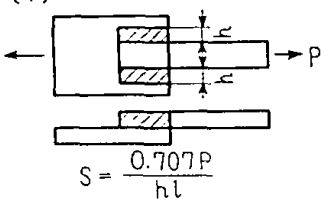

図 55 